\title{
VIAGEM PARA LEMBRAR O ESQUECIMENTO DE UM POVO OU O DESATENTO ABANDONO DE SI (UM ESTUDO DE TERRA SONAMMBULA DE MIA COUTO)
}

\author{
Jane Tutikian \\ Vivian Ignes Albertoni da Silva
}

RESUMO: The essay, based on Daniel-Henry Pageaux and Álvaro Manuel Machado theory, that distinguishes "trip literature" and "imaginative I static trip", leads to the transgression of the traditional literature that happened in the novel Terra Sonâmbula by Mia Couto, published in 1993. This transgression happens through the development of two narrative plans, in which the real objective is torn by the phenomenal manifestation of the African reality introduction, getting apart from the epic speech through the present decay. Through the mythic consciousness and dream, the author contrasts the war and the destruction to the rescue of Mozambique identity.

PALAVRAS-CHAVE: relato de viagem, viagem imaginária, viagem estática, identidade, mito, moçambicanidade.

Jane Tutikian é professora de Literatura Portuguesa e Africanas do Departamento de Letras Clássicas e Vernáculas do Instituto de Letras da UFRGS. Vivian Ignes Albertoni da Silva é acadêmica de Graduação do Instituto de Letras da UFRGS. Bolsista CNPQ. 
A viagem está incorporada desde sempre à literatura universal, da tradição greco-romana à época contemporânea. Ela se coloca, sem dúvida, como um dos temas (nos tempos modernos, fala-se em gênero) mais fascinantes, seja pelas obras que produziu - e aqui se pode referir a Bíblia, a Odisséia, a Divina Comédia, Don Quixote, Os Lusíadas...-, seja pela complexidade que adquire, se tomarmos como pressuposto que os relatos mitológicos surgem como arquétipos dos romances de aventura. Também podemos lembrar que o mesmo tema se desenvolve até desembarcar na viagem estática de um Fernando Pessoa, em $O$ marinheiro, de um Álvaro de Campos, em Opiário, ou de um Bernardo Soares, em O livro do desassossego, ou ainda do angolano Manuel dos Santos Lima, em Viagem em torno de ti. Se, em Pessoa, "para viajar basta existir" (SOARES, 1982, p. 132), Santos Lima parte e regressa como "sonho tatuado a bordo de um navio encalhado no peito de um marinheiro que jamais partiu" (LIMA, 1985, p. 100). Mas o tema também interessa porque se faz reflexão em todos os níveis: o subjetivo, por tratar-se de um relato pessoal, o histórico, o cultural, o político e o social, e, nessa reflexão, não raro, observação e imaginação se alternam e permeiam, questionando a fronteira entre observação pessoal e fato histórico "objetivamente narrável".

Aprofundando essa questão, Machado e Pageaux trazem uma distinção que nos parece interessante:

[...] a viagem imaginária apresenta sob muitos aspectos uma série de princípios invertidos em relação à narrativa de viagem. A narrativa de viagem é resposta, passagem do desconhecido ao conhecido, enquanto a viagem imaginária é interrogação sobre o universo em geral. Interrogação sobre um mundo que supúnhamos conhecer, e assim se confirma a função do tipo estrangeiro em literatura como interrogação sobre uma cultura. A narrativa de viagem é sucessão linear de descrições de locais visitados, de impressões e de experiências menos pormenorizadas; a viagem imaginária é uma peregrinação através de livros e de tradições culturais. A narrativa de viagem é uma tentativa de apropriação de idéias e de palavras, uma reconstrução verbal de um espaço mítico, espaço de substituição relativamente a um mundo tido por conhecido: aquele que é comum ao leitor e ao autor. A narrativa de viagem, pelas opções e pelas modas seguidas, é testemunho de um determinado momento da história cultural; a viagem imaginária, pelo conjunto de conhecimentos de base dos quais ela se constrói, propõe um verdadeiro itinerário intelectual, um percurso iniciático. (MACHADO \& PAGEAUX, 2001, p. 44,45)

O que se pode notar, então, é que temos, por um lado, a narrativa de viagem tradicional como uma tentativa de, através do olhar de estranhamento lançado pelo estrangeiro (que é como podemos chamar o viajante, em última instância), obter uma descrição mais objetiva, mais "eficiente" da paisagem desconhecida que se apresenta diante de seus olhos; por outro lado, temos a perspectiva da "viagem imaginária", aquela que se 
aproxima do literário, do universal, da iniciação, do desvendamento do que não é óbvio e, principalmente, da subjetividade da descrição - o papel do relato como depoimento pessoal sobre uma cultura. Assim, "quanto mais 'literária' é a narrativa de viagem, mais as suas características se fundem nas da viagem imaginária, da narrativa utópica ou da viagem romanesca", afirmam Machado e Pageaux (2001, p. 45).

Importam essas preliminares teóricas se atentarmos para o fato de que vivemos, como quer Fletcher, citado por Maria Lúcia Lepecki (1998), uma época documental, onde o "fingimento do fato" produz um "efeito histórico-documental" justamente na esfera em que se instaura o "dialogismo", dentro da perspectiva bakhtiniana de que História e ficção constituem textos distintos e em confronto, portanto, confronto de duas verdades. E, aí,

[...] se a leitura histórica, feita por via do romance, chegar a ser uma leitura crítica[... da História, então essa nova operação introduzirá [...] uma instabilidade, uma vibração, precisamente causadas pela perturbação do que poderia ter sido, quiçá tão útil a um entendimento do nosso presente como a demonstração efectiva, provocada e comprovada do que realmente aconteceu. (SARAMAGO, 1990, p. 10).

Pois esse mesmo diálogo tem, nas ex-colônias portuguesas, motivações e necessidades muito específicas. Diante do quadro de transformação e complexidade da ordem mundial na segunda metade do século 20 aliado a mutações internas, questões como nacionalismo ${ }^{1}$, identidade e alteridade terminam ocupando espaço em textos nacionais dos mais diversos estatutos, abrindo-se às plurissignificações, quando memória, História e ficção se permeiam.

Colocamo-nos, então, fundamentalmente, diante do que se pode chamar de uma "literatura de espaço":

[...] uma novelística que encara com extrema atenção o espaço romanesco enquanto escrita de uma terra cujo sentido se busca, entre a marca que a História lhe imprimiu e o curso humano que a transforma, entre a extensão determinada e a característica que a forma e o tempo que lhe ritma a sucessão e a vida. (SEIXO, 1986, p.72).

Assim, não raramente acabamos diante do desvendamento de uma multiplicidade de realidades que ficaram soterradas no tempo em determinada geografia, geradoras de presente e de futuro, entendendo, como quer Merleau-Ponty (1971, p.424) o passado e o futuro como excessos do presente ou que "o tempo não é uma linha, mas uma seqüência de

${ }^{1}$ Tomamos , aqui, como o define Edward W. Said (1995, p. 276): "restauração da comunidade, afirmação da identidade, surgimento de novas práticas culturais", dentro do pressuposto mesmo de que a nação não é uma entidade concluída, mas sujeita a mecanismos dialéticos de inclusão e exclusão. 
intencionalidades". (MERLEAU-PONTY,1971, p.420). O presente é conseqüência do passado, e o futuro conseqüência do presente. Donde se pode depreender que uma viagem no espaço é também uma viagem no tempo, e que a sequiência de espaços físicos não se constitui por obra do acaso, mas como resultado de alguma vontade.

Eis, aí, o que propõe Mia Couto, neste já considerado clássico da Literatura Moçambicana: Terra Sonâmbula, esse romance de 1993, que nos conduz ao Moçambique do nosso tempo, com seu mar, sua floresta, sua savana, sua seca, sua gente, suas crenças, seus mitos, sua guerra, traduzindo, em última análise, o drama do país do pós-independência, corroído pela guerra e por toda a espécie de tensões sociais. Esse Moçambique é desvendado por duas viagens: a do relato e a imaginária, como que buscando exorcizar a terra dessas experiências de decomposição - embora não encaminhe seu fim, porque seu fim mesmo é o começo, a pintura do retrato do seu abandono, que se constitui de forma completa quando o ciclo se fecha, e o fim do romance repete, na verdade, sua cena inicial.

De fato, a arquitetura do romance de Mia Couto é armada sobre dois planos: o real objetivo e o relato de viagem. Trata-se de associar, intercalando na construção da narrativa, dois planos que ocorrem em tempos e lugares distintos, com seus seres ficcionais, seus acontecimentos, suas situações, suas próprias tensões e emoções. Essa associação se dá pela experiência do sonho que o segundo (o relato de viagem escrito por Kindzu) produz no primeiro, desencadeando a mobilidade da estrada em que estão o velho Tuhair e o menino Muidinga, embora sua viagem permaneça como uma viagem estática.

"O que faz andar a estrada? É o sonho. Enquanto a gente sonhar a estrada permanecerá viva. É para isso que servem os caminhos, para nos fazerem parentes do futuro." (COUTO, 1995, p. 6). Essa percepção é de Tuahir, colocada como uma das epígrafes da história que se conta. E, de onde vem o sonho que mobiliza e movimenta? Do relato de viagem escrito por Kindzu. Trabalha-se, portanto, com as duas categorias da viagem detectadas por Machado e Pageaux: a narrativa de viagem, enquanto relato de experiências e descrição dos locais, e a viagem imaginária ou estática, quando se dá a peregrinação através do relato e das tradições culturais.

A viagem estática é aquela que pertence à estrada morta; é aquela que acontece num ônibus incendiado e à volta dele, somente à volta dele, $\mathrm{o}$ "machimbombo", que faz as vezes de casa.:

Naquele lugar, a guerra tinha morto a estrada. Pelos caminhos só as hienas se arrastavam, focinhando entre cinzas e poeiras. A paisagem se mestiçara de tristezas nunca vistas, em cores que se pegavam à boca. Eram cores sujas, tão sujas que tinham perdido a leveza, esquecidas da ousadia de levantar asas 
pelo azul. Aqui, o céu se tornara impossível. E os viventes se acostumaram ao chão, em resignada aprendizagem da morte. A estrada que agora se abre a nossos olhos não se entrecruza com outra nenhuma. Está mais deitada que os séculos, suportando sozinha toda a distância. Pelas bermas apodrecem carros incendiados, restos de pilhagens. Na savana em volta, apenas os embondeiros contemplam o mundo a desflorir. (COUTO, 1995, p. 9)

Portanto, numa estrada morta e num machimbombo incendiado - e recentemente, já que "os espíritos dos falecidos ainda por ali pairavam" (COUTO, 1995, p. 9) -, nada acontece, como nada acontece, além da fome, aos fugitivos da guerra, o velho Tuahir e o menino que salvara, Muidinga.

Essa situação se mantém até a descoberta, próximo do ônibus queimado, ao lado do corpo de um homem, da mala com os "cadernos escolares, gatafunhados com letras incertas" (COUTO, 1995, p.13). Enquanto sua história era apenas mais um relato de viagem por um país destruído pela guerra incessante, Tuahir e Muidinga "condiziam com a estrada, murchos e desesperançados." (COUTO, 1995, p. 10); nesse sentido, a viagem imaginária termina configurando, como querem Machado e Pageaux, um percurso iniciático, pois é o sonho provocado pelo relato de Kindzu que desperta a mobilidade da outra estrada, possibilitando a viagem estática dos protagonistas. E, como toda a grande viagem, esta também se faz por mar: "um mar cheio de fantasias infinitas". (COUTO, 1995, p. 235).

A partir da descoberta e do início da leitura dos cadernos é que a paisagem começa a mudar em volta do ônibus:

Então se admira: aquela árvore, um djambalaueiro, estava ali no dia anterior? Não, não estava. Como podia ter-lhe escapado a presenca de tão distinta árvore? E onde estava a palmeira pequena que, na véspera, dava graça aos arredores do machimbombo? Desaparecera! A única árvore que permanecia em seu lugar era o embondeiro, suportando a testa do machimbombo. Seria coisa de crer aquelas mudanças na paisagem? (COUTO, 1995, p. 44)

Ou:

Diria ao miúdo que aceitava partir. Depois fingiria afastar-se, enquanto andavam em círculos. Regressariam sempre ao machimbombo, à mesma estrada de onde haviam partido. Assim ele fizera desde a primeira vez que saíram da estrada.

Nessa tarde, o velho comanda uma dessas falsas viagens. Primeiro, seguem ao longo da picada. A estrada onde moram surge a Muidinga com novas vistas, parecendo pentear a savana, risco ao meio. (COUTO, 1995, p. 78)

$\mathrm{Ou}$, de uma forma mais definitiva:

À volta do machimbombo Muidinga quase já não reconhece nada. A paisagem prossegue suas infatigáveis mudanças. Será que a terra, ela sozinha, deambula em errâncias? De uma coisa Muidinga está certo: não é o arruinado autocarro que se desloca. Outra certeza ele tem: nem sempre a estrada se movimenta. 
Apenas de cada vez que ele lê os cadernos de Kindzu. No dia seguinte à leitura, seus olhos desembocam em outras visões.

(COUTO, 1995, p. 121)

É neste movimento do sonho e da fantasia que a viagem assume sua forma mítica como iniciação, como procura, como libertação simbólica e revelação. Pela estrada passam figuras alegóricas, portadoras da tradição e da esperança restauradora do país.

À solidão e destruição da guerra contrapõe-se o velho Siqueleto, o semeador de gente:

Tuahir traduz:

- Ele diz que nos vai semear.

- Semear?

-Não sabe o que é semear? É isso que nos vai fazer. Ele quer companhia, quer que nasça gente.

(COUTO, 1995, p. 80)

E justifica-se: todos haviam ido embora daquele lugar, por motivo de terror, porque os bandos assaltaram, mataram, queimaram e a aldeia foi ficando deserta; era, portanto, preciso semear gente. Ele próprio se transforma em semente quando seu nome é escrito na árvore. Ora, a árvore, na cultura africana, é vista como agente cíclico da evolução cósmica: morte e regeneração. Assim, ao transformar-se em semente, Siqueleto incorpora-se ao mundo vegetal, predispondo-se ao eterno ciclo do nascer, morrer e renascer, vencendo a solidão, mas, mais do que isso, vencendo a morte física e cultural.

À seca, à fome e desesperança da guerra, contrapõe-se Nhamataca, o fazedor de rios:

- Estou a fazer um rio, responde o outro.

Riem-se, o rapaz e Tuahir. Mas o homem insiste, no sério. Sim, por aquele leito fundo haveria de cursar um rio, fluviando até o infinito mar. As águas haveriam de nutrir as muitas sedes, confeitar peixes e terras. E seria o parto da terra, do lugar onde os homens guardariam, de novo, suas vidas.

$[\ldots]$

O sujeito desafiava os deuses que aprontaram o mundo para os viventes dele só se servirem, sem ousarem mudar a sua obra. Mas Nhamataca não desistiu, covando no dia a noite. Foi seguindo, serpenteando entre vales e colinas, suas mãos deitando e renovando mil vezes as sangradas e calejadas peles. E agora, sentado na ribanceira, guarda com vaidade sua construçã̃o. Aponta o fundo:

- Vejam: já aponta um fiozinho de água.

Tal agüinha nem se via. Havia, quando muito, um suor na areia do fundo. Mas os visitantes não contrariam.

- E que nome ele vai ter?

Nome que dera ao rio: Mãe-água. Porque o rio tinha vocação para se tornar doce, arrastada criatura. Nunca subiria em fúrias, nunca se deixaria apagar no chão. Suas águas serviriam de fronteira para a guerra. Homem ou barco carregando arma iriam ao fundo, sem regresso. A morte ficaria confinada ao outro lado. O rio limparia a terra, cariciando suas feridas. (COUTO, 1995, p.105) 
Como Nhamataca dedica sua vida à construção do rio, projetando nele as suas esperanças de um mundo abundante, constrói, também, como observa Tania Macêdo (2000), a metáfora da utopia no sentido que the confere Ernst Bloch: o sonho acordado que mobiliza as energias humanas para construir, pelo esforço cotidiano, o futuro para uma terra desencantada e desenraizada pela guerra.

À praga dos gafanhotos, contrapõem-se as velhas mulheres, em cerimônia sagrada. Elas surgem como elemento cultural desconhecido para o menino Muidinga, que é agredido e abusado por elas. Coloca-se, então, uma dificuldade de comunicação entre diferentes gerações que já se colocara entre o velho e o menino, desde as primeiras cenas do romance. Essa dificuldade vai sendo vencida à medida em que o tempo passa e a leitura dos cadernos de Kindzu avança. Na verdade, tudo acontece perto do ônibus incendiado, e tudo o que acontece não é mais do que Moçambique, o país, que passa por ali, um país "sonhambulante" (COUTO, 1995, p. 165), com Siqueleto virando semente, Nhamataca fazendo o rio, as velhas caçando gafanhotos. Um país interrompido pela guerra, da mesma forma com que foram interrompidos os trens que antes rasgavam a savana, trazendo simpatias e mineiros carregados de mil ofertas, trazendo, enfim, vida, já que "Foi o que fez essa guerra: agora todos estamos sozinhos, mortos e vivos. Agora já não há país." (COUTO, 1995, p. 185)

"Trata-se", segundo Machado e Pageaux, "duma escrita que pretende transformar o que era fortuito, fruto do acaso, em experiência necessária, em etapas duma vida. Escrever um texto de viagem é sempre transformar, mais ou menos, o efêmero em necessário, o acaso em revelação." (MACHADO \& PAGEAUX, 2001, p. 43). E para a revelação, Tahuir, o velho, em conformidade com a tradição africana, transforma-se na consciência externa do menino, até por ser ele o detentor da sabedoria popular, e revela-se como um guardador da esperança: "Que a nossa terra se ia aquietar, todos se familiariam, moçambicanos. E nos visitaríamos, como nos tempos, roendo os caminhos sem nunca mais termos medo." (COUTO, 1995, p. 82), para sentenciar mais adiante: "ouviu falar de países ricos onde a gente já nem tem que cavar a terra: enterra-se a enxada, bem direito no chão. Do cabo brotam árvores, plantas cheias de verde. - Seremos assim também." (COUTO, 1995, p. 82)

O trajeto de Muidinga, paralelo ao percurso da viagem imaginária, é o de busca de si, da sua própria identidade. Como a terra, ele fora envenenado pela guerra e perdera a memória e a si mesmo. E, não circunstancialmente, cabe ao velho auxiliá-lo a recuperar suas lembranças, denunciando, já, no projeto de moçambicanidade de Mia Couto, a busca da unidade que as contingências históricas procuram truncar. 
A estrutura arquitetada no romance aponta para o relato de viagem como o outro plano narrativo que aparece intercalado ao real objetivo, à viagem estática ou imaginária. Se essa estrutura, por si só, é transgressora da literatura de viagem tradicional, o próprio relato também o é. Já nos referimos, no início deste texto, a algumas grandes obras em que o tema da viagem se eleva como motivo; pois cabe dizer que vários elementos dessas obras estão presentes em Terra Sonâmbula. É notável, por exemplo, a semelhança entre o momento em que Kindzu, o protagonista das viagens narradas nos cadernos lidos pelo menino e o velho, precisa lutar contra a tentação causada por vozes que o atraem para Farida, parecendo terem por objetivo tentá-lo a não partir - da mesma forma que as sereias tentavam os marinheiros, na Odisséia. Em diversos momentos do romance há fortes semelhanças com narrativas de viagem em geral (pois, afinal, a subversão do gênero só se torna possível a partir da estrutura do próprio gênero), mas também traços em comum com as epopéias. Sua composição traz elementos próprios às grandes narrativas épicas - o mar, os obstáculos do mundo e as armadilhas das figuras mitológicas, o amor e a busca do ser ideal como ideal de representação de um povo - entretanto, seu tempo é o presente histórico e, como tal, anula a possibilidade de uma épopéia, conforme nos ensina Bakhtin. Segundo o autor, o tempo real da experiência contrapõe-se à distância e à totalidade épicas pela característica de finitude essencial do presente e da existência, ou

[...] l'epopée, genre précis, comporte trois traits constitutifs: 1. Elle cherche son objet dans le passé épique national, le "passé absolu", selon la terminologie de Goethe et Schiller. 2. La source de l'épopée c'est la légende nationale (et non une experience individuelle et la libre invention Qui en découle). 3. Le monde épique est coupé par la distance épique absolue du temps présent: celui de l'aede, de l'auteur et de ses auditeurs. (BAKHTIN, 1978, p. 449)

L'époque contemporaine, en tant que telle, avec son aspect d'actualité vivante, ne pouvait (...) servir d'objet de réprésentation pour les genres élévés. (...)Le présent est transitoire, fugace, c'est une sorte de continuité éternelle, sans commencement ni fin (...)Le futur était pensé soit comme le prolongement du présent, soi comme fin, destruction ultime, catastrofe. (BAKHTIN, 1978, p. 455)

Assim, o relato escrito por Kindzu, produtor, organizador e objeto da narrativa estabelece-se como registro de memória, mas sobretudo como ordenador dos tempos:

Quero pôr os tempos, em sua mansa ordem, conforme esperas e sofrências. Mas as lembranças desobedecem, entre a vontade de serem nada e o gosto de me roubarem o presente. Acendo a estória, me apago a mim. No fim destes escritos, serei de novo uma sombra sem voz. (COUTO, 1995, p. 17)

Isso se justifica porque o tempo é o do pós-independência, o da guerra civil, "um tempo em que o tempo não acontece" (COUTO, 1995, 
p.27), um tempo de casas vazias, de fugas, de bandos de assaltantes, de balas certeiras e perdidas, de selvageria.

É com Surendra, o comerciante indiano, que a viagem começa a ser preparada pelo encontro com a raça especial, acima das raças, "os índicos", "os da costa", habitantes "não de um continente mas de um oceano."(COUTO, 1995, p. 29), a história comum de sangues misturados. E é também no estabelecimento de Surendra que se dá o encontro com o homem ideal com figurações de herói, um dos naparamas: "guerreiros tradicionais, abençoados pelos feiticeiros, que lutavam contra os fazedores da guerra."(...) "Combatiam com lanças, zagaias, arcos. Nenhum tiro lhes incomodava, eles estavam blindados, protegidos contra balas." (COUTO, 1995, p. 31). Eram "guerreiros de justiças" (COUTO, 1995, p. 34). É, também, aí que se dá a decisão de ser um naparama, embora sair daquele mundo significasse carregar consigo a assombração do pai, numa realidade em que o sobrenatural apresenta-se como natural. A viagem estava traçada como resgate de uma raça acima das raças através de um herói justiceiro e vingador do sofrimento de sua gente.

Vem do conselho dos anciãos o mote final para a viagem: “- Está ver, todos linhados? Isso quer dizer: você é um homem de viagem. E aqui vejo água, vejo mar." (COUTO, 1995, p. 37) e está colocado seu fado posto que é mar - a história escrita a priori por um espírito pré-existente cujo destino é caminhar e não, chegar.

A viagem inicia com a descrição do esforço entre mar e terra, no litoral, mas também do assombramento de uma cultura essencialmente mítica, e a sua primeira parte não é mais do que a descida ao inferno, como a de Enéas, em Virgílio, diferentemente do inferno cristão de Dante:

Suas formas não figuravam um desenho de descrever, semelhando um maufeitor vindo dos infernos. Sempre eu só ouvira falar deles, os psipocos ${ }^{2}$, fantasmas que se contentam com nossos sofrimentos. Ali estava um deles, inteiro de sombra e fumo. Segurou a pá e começou a covar. (...)

Me encolhi acreditando serem meus finais tormentos. Por modos de dizer, eu mijava pelos calcanhares. Mas a morte é um repente que demora. A aparição se abaixou e disse:

-Fica saber: o chão deste mundo é o teto de um mundo mais baixo. E sucessivamente, até ao centro onde mora o primeiro dos mortos. (COUTO, 1995, p. 51)

Se o inferno está povoado de almas, espécie de duplos imateriais ou sombras dos seres vivos, levando uma vida larvar num mundo de brumas, atormentada pela memória da vida terrestre, conhecê-lo, ainda que como um grande pesadelo e vencê-lo, pelo conhecimento do segredo das

${ }^{2}$ Psipoco ou xipoco: fantasma 
coisas, confirma um estatuto heróico e mítico num modelo de procura iniciática. Esse é um aspecto muito forte numa cultura mítica, quando a ruptura com o real não é criada, mas trazida à ficção na transposição da própria cultura, numa espécie de linguagem adequada à descrição de modelos eternos de comportamento, de certas leis essenciais do cosmo social e natural. Assim, o mito não é uma narrativa alegórica ou simbólica. Ele é vivência de uma realidade relacionada ao destino humano e ao destino do cosmo, embora se mantenha sua definição como representação por meio de imagens fantásticas do mundo, de deuses e espíritos que o regem.

A primeira escala apontada pelo relato de viagem é a Baía de Matimati, assim descrita:

A vila se deitava no abraço da água, parecia que estava ali mesmo antes de haver mar: $\mathrm{O}$ que testemunhei naquela povoação foram coisas sem hábito neste mundo. Gentes imensas se concentravam na praia como se fossem destrocos trazidos pelas ondas. A verdade era outra: tinham vindo do interior, das terras onde os matadores tinham proclamado o seu reino. (COUTO, 1995, p. 67)

Neste ponto, o espaço se lhe afigura como estrangeiro. Descobre, no seu mesmo, o outro, o comportamento e a psicologia da guerra e, paralelamente, descobre-se a si, que deixara, na partida, a infância.

Também, aí, em Matimati, a herança cultural se faz presente através do realismo mágico, através de tchóti, o anão que desce do céu em busca de riquezas que lá faltam e o conduz ao "barco espiritado", vazio, solitário, onde se ouvem “vozes, ordens, gritos, gemidos."(COUTO, 1995, p. 74) Sua representação apresenta-se como fenomênica e não ilusória, o que nos remete ao pensamento de Cassirer (1959) de que deixa de existir possibilidade de análise lógica do pensamento mítico, ressaltando a particularidade da fantasia mítica de combinar a espiritualização do cosmo com a materialização dos conteúdos espirituais e a mitologia é também social e ideológica.

É no barco enfeitiçado que encontra o amor, que constitui obstáculo. Lá, ele encontra Farida, bela e sedutora a exemplo das Náiades, mas, mais do que elas, membro da família dos xipocos:

Sei que sou um deles, um espírito que vagueia em desordem por não saber a exata fronteira que nos separa de vocês, os viventes. Nós somos sombras no teu mundo, tu jamais nos tinhas escutado. E porque vivemos do outro lado da terra, como o bicho que mora dentro do fruto. Tu estás do lado de fora da casca. Eu já te tinha visto desse outro lado, mas as tuas linhas eram de água, teu rosto era cacimbo. Fui eu que te trouxe, fui eu que te chamei. Quando queremos que vocês, os da luz, venham até nós, espetamos uma semente no teto do mundo. Tu foste um que semeamos, nasceste da nossa vontade. Eu sabia que vinhas. Te esperava, Kindzu. (COUTO, 1995, p. 101) 
Farida, a filha do céu, constitui prova, desvio de rota e desvio de vida: há que escolher entre ser um naparama ou cumprir o destino de Farida - marcado pela tradição desde o fato de ser gêmea e os gêmeos deviam ser separados e um deles morto, para que a má sorte não caísse sobre a aldeia - buscando o filho perdido da mulher, Gaspar. Ou isso ou perder o amor, porque "Farida não aceitaria a minha falta de promessa. E ela se afastaria de mim, partiria para inalcançável longe.” (COUTO, 1995, p. 237)

Em busca de Gaspar, essa termina sendo a opção, a primeira escala é a vila de Matimati e, aí, pelo viés do sentimento, a paisagem se torna, novamente, outra, já que, apesar da ruína, o amor ilude o olhar do viajante: "Ao avistar a praia de Matimati, comprovei como são nossos olhos que fazem o belo. Meu estado de paixão puxava um novo lustro àquela terra em ruínas. Aquelas visões, dias antes, já tinham estado em meus olhos. Porém, agora tudo me parecia mais cheio de cores, em assembléia de belezas." (COUTO, 1995, p. 127) Entretanto, a guerra, uma guerra-fantasma, com um exército "temido por todos, mandado por ninguém" (COUTO, 1995, p.134), com seus grupos de homens prontos a armar o inferno, é pura destruição e traz consigo a consciência de que: "nós, que nascêramos naquele tempo, éramos os últimos viventes. Depois de nós já não havia mundo para receber mais ninguém." (COUTO, 1995, p. 147) Quer dizer, ao fundir suas personagens misticamente com a paisagem, Mia Couto transforma a viagem em reflexão histórico-cultural.

A notícia da morte de Farida - e portanto o amor não se realiza - é o início do retorno. Agora, a viagem não é mais por mar, mas por terra, e a predição dos velhos de que a viagem de Kindzu é sempre partida, não chega, mas recomeça, se concretiza. Ele se encaminha para o machimbombo, espaço de fusão entre as duas viagens (e os dois planos da narrativa): a de Kindzu e a do velho Tahuir e do menino. A busca de Kindzu se realiza no sonho da morte - e na cultura mítica, segundo pensamento de Ernest Cassirer (1959), distingue-se apenas precariamente a realidade imediata e o significado mediatizador. Vida e morte não se delimitam entre si, são partes homogêneas da existência. - ele personifica o ideal de um novo moçambicano, justiceiro, herói da paz, tornando-se um naparama, e ele encontra Gaspar (que era, na verdade, o menino acompanhante de Tahuir). O herói que, afinal, cumpre o seu destino é, durante toda a viagem - a do relato -, confrontado com o meio, o real e o mágico africano. Esse confronto contribui para a sua formação moral. O ângulo de visão que se coloca no relato é o do narrador - Kindzu - o resto, personagens e descrição dos lugares, são sensações, impressões e experiências suas, fazendo dele um desvendador da moçambicanidade, ou seja, um revelador da cultura e da identidade moçambicanas. 
É de se notar que a história do colonialismo português, em Moçambique, como nas demais colônias, está ligada a um processo de superposição cultural ao lado dos mecanismos econômicos de exploração das riquezas naturais e tráfico de escravos. A própria implantação e desenvolvimento do colonial-capitalismo foi escorada num processo bastante violento de opressão e alienação cultural. Afirmam os escritores moçambicanos, em 1979, na $6^{a}$ Conferência dos escritores Afro-Asiáticos, realizada em Luanda:

Não se tratava para o capitalismo - como a sua propaganda garantia- de levar a "civilização" (entenda-se a cultura portuguesa) aos povos que dominava. Sendo este, embora, o pretexto, a questão central era a destruição das culturas dessas comunidades, ou seja, da sua capacidade de se identificarem como povo.

Pretendia-se romper os laços do povo com o seu passado, com a sua História - particularmente com a História da sua resistência à penetração colonial - estilhaçar a sua visão do mundo e da sociedade, privá-lo das formas de expressão que desenvolvera, desligá-lo até do seu espaço geográfico, amputandoo assim dos elementos que definiam a sua personalidade e impedindo-lhe que esses elementos, dentro da lógica de desenvolvimento das sociedades, se transformassem no cimento aglutinador da unidade nacional.

Assim se pode compreender que, enquanto reprimia brutalmente as expressões culturais do povo, a máquina de imposição dos modelos culturais da burguesia colonial era mediocremente eficiente fora das cidades e no exterior dos estratos sujeitos ao processo de assimilação.

Para a maioria esmagadora do povo, a cultura imposta pelo colonizador identificava-se, por um lado, com a negacão violenta da sua própria... (HONWANA; CRAVEIRINHA; NOGAR, 1981, p. 188)

É o que o Presidente Samora Machel, à época Presidente de Moçambique, sintetiza assim em entrevista ao jornal brasileiro Pasquim, em 1979:

Alguns não gostaram de cortar o cordão umbilical com o colonialismo. O padrasto se foi. Como ficamos agora? Estavam habituados a que alguém os "protegesse". Sentiram-se órfãos com a independência real que conquistamos. [...]

Essa foi a educação do colonialismo: fazer-nos aceitar sua música, sua história, seu passado, como nossa música, nossa história, nosso passado. [...]

Os meninos negros são sabiam desenhar os negros. Só aprendiam a desenhar meninos brancos. (MACHEL, 1979, p. 2)

Essas são marcas de que não se pode desfazer. Segundo Edward Said (1995, p. 267) os africanos da descolonização julgaram necessário reimaginar uma África - a partir do que foi exposto - despojada do seu passado imperial para concluir pela imutabilidade do passado e da presença do Outro, o português, no próprio processo identitário, como força construtora, com todas as premissas que o imperialismo traz consigo.

Os escritores pós- imperiais do Terceiro Mundo, portanto, tra- 
zem dentro de si o passado - como cicatrizes de feridas humilhantes como uma instigação de práticas diferentes, como visões potencialmente revistas do passado que tendem para um futuro pós-colonial, com experiências urgentemente reinterpretáveis e revivíveis, em que o nativo outrora silencioso fala e age em território tomado pelo colonizador, como parte de um movimento geral de resistência. (SAID, 1995, p. 267)

Nesse sentido, o esforço cultural pela descolonização traz consigo um esforço pela restauração da comunidade e pela retomada da cultura enfim, entendendo-se a cultura como manancial de identidade, o que continua, por muito tempo, após o estabelecimento do Estado independente. $\mathrm{E}$, aqui, quando se fala em projeto voltado para o nacionalismo, fala-se em restauração da comunidade, em afirmação da identidade, em resgate de práticas autênticas e surgimento de novas práticas culturais. Mas, em Moçambique, (como em Angola ou na Guiné) fala-se, também de um projeto adiado pela guerra civil, com toda a violência, que sucede à descolonização.

O país chega à independência total em 1975, sob o governo marxista da Frente pela Libertação de Moçambique (FRELIMO), chefiado por Samora Machel. Meio milhão de brancos deixam o país, que se ressente do êxodo populacional e da evasão de mão-de-obra qualificada. A estrutura de mercado desmorona sem que o governo da FRELIMO consiga implantar o modelo econômico socialista. Para agravar a situação, entra em cena, nos anos 70, a guerrilha da Resistência Nacional Moçambicana (RENAMO), grupo anticomunista apoiado pelo governo branco da África do Sul, que passa a combater a Frente pela Libertação de Moçambique. Na década de 80, a seca e a continuidade da guerra civil provocam a fome em grande escala,- o espaço relatado por Mia Couto, em Terra Sonâmbula. Em 1984, o país assina com a África do Sul um tratado de não-agressão, logo violado pelo governo sul-africano, que mantém a ajuda à RENAMO. O processo de pacificação inicia apenas na década de 90 e as duas partes assinam um acordo de paz em 1992. A estabilização é difícil. A miséria é generalizada e a incidência de tifo e cólera é alta. Há minas terrestres em grande parte do território, dificultando o cultivo da terra.

A verdade é que os quase 20 anos de guerra civil, terminada em 1992, devastaram a nação: deixaram um milhão de mortos e milhares de minas terrestres, que continuam matando e mutilando as pessoas. Uma nação, portanto, espacial e culturalmente destruída e em crise de identidade

Nesta "terra sonâmbula" o destino heróico de Kindzu se cumpre no fechamento de uma estrutura circular em que os dois planos da narrativa se encontram, quando as viagens se cruzam. Assim, a partir do resgate 
da História e da História Cultural, ele descobre o seu próprio país, um país que lhe é estranho. E a recomposição de sua biografia, pelo relato de viagem, ordenador dos tempos, dá a conhecer Moçambique ao velho Tahuir e ao menino Muidinga.

No relato de Kindzu, ao contrário do que acontecia na viagem estática, figuras como a do sábio indiano Surendra, ou da tia de Farida, Euzinha, tendem a se perder, na loucura ou na desesperança. Kindzu conhece seu passado, mas vai perdendo seus referenciais - o pai, Surendra, a sempre perseguida figura do valoroso guerreiro tradicional, o naparama. Enquanto isso, o menino quer conhecer seu passado, quer recordar, quer entender o presente.

O resultado desses percursos é que, por se afastarem tanto, eles acabam se encontrando. Kindzu já não continuará vivendo, mas Muidinga, na verdade, agora recebeu uma identidade - a do filho perdido de Farida, Gaspar. Kindzu levara-o ao sonho, fizera-o viajar por sua própria cultura e conhecê-la, e como último gesto, ainda fora capaz de dizer-lhe seu verdadeiro nome, o que sugere que a geração de Kindzu passou por todos os horrores da guerra e coloca-os diante dos olhos da geração de MuidingaGaspar, a geração que tem de seguir adiante, possuindo a vantagem de conhecer seu passado e sua tradição, coisas que Kindzu se dispusera a organizar, ao escrever sua quase epopéia. Podemos chamá-la assim pois, como um texto fundante, esse romance se ocupa em dar conta da "formação" de seu país, caracterizando-o e dando-lhe um mito; mas convém lembrar que Terra Sonâmbula é escrito utilizando o presente e o texto se projeta para o futuro, não se limitando a explicar o passado. O que se exige de Muidinga, ao revelar-se seu nome, não é que se satisfaça com a descoberta, mas que prossiga, como sugere a última cena do romance, que acaba no exato momento em que mais um ciclo começará - desta vez nas mãos de Muidinga-Gaspar, pois tanto Tuhair quanto Kindzu morrem, durante suas respectivas viagens. Viagens que fizeram, aliás, de certa forma, pelo menino.

A utilização dos dois planos intercalados termina transformando a narrativa num problema de arte. A linguagem, em Mia Couto, seguidor confesso do brasileiro Guimarães Rosa e do angolano Luandino Vieira, é suporte eficaz de imagens vivas. Assim, além do trabalho transgressor com as características esperadas de um relato de viagem, e que acabam resultando na produção de novos sentidos dentro da estrutura do romance, também temos o trabalho com a linguagem, seja pela apreensão da oralidade, seja por uma nova organização sintática, seja pela utilização de diferentes recursos estilísticos, seja, sobretudo, na utilização do léxico projetado na 
geração de novos termos, enriquecidos de significado, atingindo, por vezes, um caráter lúdico em que brilha, principalmente, a forma oralizante do discurso.

Os métodos utilizados nesse trabalho de enriquecimento lingüístico variam, mantendo em comum a ampliação das possibilidades interpretativas do texto: por vezes, acontece a união de dois vocábulos que causam estranhamento por estarem juntos ("líquidos assuntos" (COUTO, 1995,p.155 ), em outros casos temos a criação, a partir da síntese de duas palavras, de uma terceira, que expressa a relação íntima entre as duas primeiras, dentro do universo ficcional do romance ("Riu-se, espalhafarto"3 (COUTO, 1995, p. 155). Há ainda as ocorrências em que uma palavra normalmente apresentada numa classe aparece em outra ("a terra arcoiriscando"4 (COUTO, 1995, p. 183). E, associada a esses procedimentos, há uma outra faceta de extremo valor: o lirismo de várias passagens, nas quais o uso de metáforas exibe o lado mais sensível da prosa de Mia Couto.

Em todos esses momentos, o que se vê é a exploração de novas possibilidades lingüísticas, que colaboram na instauração e caracterização do universo ficcional. Ao mesmo tempo em que aflora no texto a inquietação estética do autor, que, é necessário enfatizar, não é gratuita, mas vinculada à procura da imagem mais fiel e mais viva, como a própria inquietação da literatura ocidental da segunda metade do século 20, há todo um processo de recolha dos diferentes falares moçambicanos, próprios das zonas rurais do país. É, como afirma Fernanda Cavacas, onde "recolhe a seiva de vida autêntica que alimenta a ficção das escrevências." (CAVACAS, 2000 , p. 235). É como expressa as comunidades africanas em seus aspectos ontológicos e sociológicos.

Assim, o documento está lá, mas a arte o perpassa e, despojado da mentalidade colonial, o autor empreende a busca da própria identidade nacional, com seus espaços míticos, mas sem perder de vista o caráter universal da sua criação. Confirma-se a idéia de Fehér (1972, p. 6), citando Luckács, de que o período da epopéia é caracterizado pela segurança, quando vida e essência são noções idênticas; o romance, por sua vez, é a epopéia de uma época para a qual a totalidade (e, corolariamente a homogeneidade reinante no mundo, a substancialidade humana, a relação substancial entre o homem e seus produtos) não passa de um problema de aspiração. É quando, em Mia Couto, o presente retoma a consciência mítica, buscando recuperar certos valores autóctones de raízes específicas, capa-

${ }^{3} \mathrm{O}$ grifo é nosso.
${ }^{4} \mathrm{O}$ grifo é nosso. 
zes de clarificar a consciência ou identidade nacional.

Se tempos e povos possuem a sua mitologia e se ela reflete o pensamento espontâneo de cada variedade de homens, o mito se traduz por uma espécie de alma íntima, de expressão sintética onde se encontram fundidas e unificadas todas as suas faces. Da admiração e do medo gerados pelo instinto do conhecimento é que nascem os mitos, como visões da imaginação e impressões dos sentidos.

Em Terra Sonâmbula, sua representação gera a afirmação de uma identidade cultural que transgride uma identidade racional, a européia, imposta pelo colonialismo. Predomina a invenção dos espíritos ou almas, seres fantásticos das sombras, como representação do mundo cósmico e seus fenômenos e do mundo físico com seus sonhos e alucinações. Nas suas relações, há a decorrência de rito através do qual se luta e se quer afastar os demônios e os espíritos ruins e as maldições. E, o que importa, ligada a essa realidade predomina o apego à terra, com sua destruição, sua miséria, sua fome, porque a terra é o elemento fundamental da identidade.

Segundo Merleau-Ponty, o "mito tem sua essência na aparência, o fenômeno mítico não é uma representação, mas uma verdadeira presença." (MERLEAU-PONTY, 1971, p. 295) É por esse viés que, através das viagens empreendidas num mundo esfacelado pela guerra civil, de perplexidade e incerteza, da qual suas personagens se fazem testemunho de uma geração e de uma época, a possibilidade de reconstrução está colocada no resgate de uma consciência mítica, pois "a consciência mítica está aberta sobre um horizonte de objetivações possíveis." Assim, o mito, por mais "difuso que possa estar (...), forma um mundo, isto é, uma totalidade onde cada elemento tem relações de sentido com os outros." (MERLEAUPONTY, 1971, p. 297). Daí porque, em Mia Couto, o tempo nasce na relação com as coisas e a relação com as coisas está no sonho - aqui despertado pela viagem através de uma escrita fortemente vinculada à terra quando memória pode ser futuro, ratificando a idéia de Tania Macêdo de que Terra Sonâmbula está entre aqueles textos que "buscam resgatar, pela fantasia, o amor à terra num mundo desencantado e desenraizado." (MACÊDO, 2000, p. 673).

Em outras palavras, é no sonho - que transforma o relato de viagem de Kindzu, como querem Machado e Pageaux, na reconstrução verbal de um espaço mítico, e a viagem estática de Muidinga em percurso iniciático - que Mia Couto deposita o seu grande projeto literário, o projeto da moçambicanidade, o desvendamento da identidade de um país esquecido de si devido aos mecanismos impostos pelo curso da História e pela guerra civil, a tentativa de despertá-lo do desatento abandono de si. 


\section{BIBLIOGRAFIA}

BAKHTIN, Mikhail. Esthétique et théorie du roman. Paris, Gallimard, 1978.

. Problemas da poética de Dostoievski. Traduzido por Paulo Bezerra. Rio de Janeiro, Forense Universitária, 1981.

CASSIRER, Ernest. Mito y lenguage. Buenos Aires, Galatea Nueva Vision, 1959.

CAVACAS, Fernanda. Mia Couto: brincriação vocabular. In: DUARTE, Lélia Parreira. (org.) Veredas de Rosa; Seminário Internacional Guimarães Rosa, 1998-2000. Belo Horizonte, PUC Minas/CESPUC, 2000. COUTO, Mia. Terra sonâmbula. Rio de Janeiro, Nova Fronteira, 1995.

FEHÉR, Ferenc. O romance está morrendo? Rio de Janeiro, Paz e Terra, 1972.

HONWANA, Luís Bernardo; CRAVEIRINHA, José; NOGAR, Rui. A questão da cultura moçambicana. In: Documentos da VI Conferência dos escritores Afro-Asiáticos. Lisboa, União dos Escritores Angolanos/Edições 70, 1981. V.2

LEPECKI, Maria Lúcia. Aspectos da narrativa de preocupação histórica em Portugal, hoje. Coimbra, Associação Nacional dos Lusitanistas / POITIEPS, 1988.

LIMA, Manuel dos Santos. Viagem em torno de ti. In:CECHIN, Lúcia. (org.) Antologia angolana. Poesia e conto. Porto Alegre, ED. da UFRGS, 1985.

LLOSA, Mario Vargas. La novela. Montevideo, Fondo de Cultura Universitaria, 1968.

MACÊDO, Tânia. O rio e seus (dis)cursos em Rosa, Luandino e Mia Couto. In: DUARTE, Lélia Parreira. (org.) Veredas de Rosa; Seminário Internacional Guimarães Rosa, 1998-2000. Belo Horizonte, PUC Minas/ CESPUC, 2000.

MACHADO, Álvaro Manuel; PAGEAUX, Daniel-Henry. Literatura portuguesa Literatura comparada Teoria da literatura. 2 ed. Lisboa, Presença, 2001.

MACHEL, Samora. Entrevista. Pasquim. São Paulo, p.2-6 jun. 1979.

MARTIN, René. (org.) Dicionário cultural da mitologia greco-romana. Lisboa, Dom Quixote, 1995.

MARTINS, J.P. Oliveira. Systema dos mitos religiosos. Lisboa, Bertrand, s.d. 
MERLEAU-PONTY, M. Fenomenologia da percepção. Traduzido por Reginaldo Di Piero. Rio de Janeiro, Freitas Bastos, 1971.

SAID, Edward W. Cultura e imperialismo. Traduzido por Denise Bottman. São Paulo, Companhia das Letras, 1995.

SARAMAGO, José. História e ficção. Jornal de Letras, Lisboa, n. 400, p. 4-5 ,abr. 1990.

SEIXO, Maria Alzira. Escrever a terra- sobre a inserção do espaço no romance português contemporâneo. In:__. A palavra do romance- Ensaios de genologia e análise. Lisboa, Livros Horizonte, 1986.

SOARES, Bernardo. O livro do desassossego. Lisboa, Ática, 1982. 